\title{
Profil penyakit infeksi kulit karena virus pada anak di Divisi Dermatologi Anak Poliklinik Ilmu Kesehatan Kulit dan Kelamin RSUP Prof. Dr. R. D. Kandou Manado periode tahun 2013 - 2015
}

\author{
${ }^{1}$ Anthony S. Wibawa \\ ${ }^{1}$ Ellen Gunawan \\ ${ }^{2}$ Herry E. J. Pandaleke \\ ${ }^{3}$ Aryani Adji
}

\author{
${ }^{1}$ Program Studi Ilmu Penyakit Kulit dan Kelamin Fakultas Kedokteran \\ Universitas Sam Ratulangi Manado \\ ${ }^{2}$ Bagian Ilmu Kesehatan Kulit dan Kelamin Fakultas Kedokteran \\ Universitas Sam Ratulangi Manado \\ ${ }^{3}$ KSM RSUP Prof. Dr. R. D. Kandou Manado \\ Email: anthony_surya@hotmail.com
}

\begin{abstract}
Viral skin infection can occur in all ages, especially in children. These viruses can cause skin lesions due to the viral replication in the epidermis or as a secondary effect of viral replication in other part of the body. This study was aimed to obtain the profile of viral skin infections in Pediatric Dermatology Division of Dermatovenereology Clinic, Prof. Dr. R. D. Kandou Hospital Manado from 2013 to 2015. This was a retrospective study using medical records of new pediatric patients with viral skin diseases, aged 0-14 years from 2013 to 2015 . The results showed that there were 113 pediatric patients $(12.71 \%)$ with viral skin infections. The majority of cases were 5-14 years old $(73.45 \%)$, followed by $1-4$ years old $(25.66 \%)$ and $0-1$ years old $(0.88 \%)$; females $(52,21 \%)$ were more commonly found. The viral skin diseases in this study were moluscum kontagiosum $(47.79 \%)$, verucca vulgaris (29.20\%), varicella (8.85\%), herpes zoster (7.97\%), and hand foot mouth disease $(6.19 \%)$. Conclusion: Skin viral diseases in children were found in $12.71 \%$ of new patients, most common in females and aged 5-14 years. Moluscum contagiosum was the most common skin viral disease in all ages.
\end{abstract}

Kata kunci: penyakit kulit, infeksi virus, anak

\begin{abstract}
Abstrak: Penyakit infeksi kulit karena virus dapat terjadi pada semua usia, tetapi lebih banyak pada anak-anak. Virus dapat menyebabkan timbulnya lesi kulit sebagai hasil dari replikasi virus di epidermis atau sebagai efek sekunder replikasi virus di tempat lain pada tubuh. Penelitian ini bertujuan untuk mengetahui profil penyakit infeksi kulit karena virus pada anak di Divisi Dermatologi Anak Poliklinik Ilmu Kesehatan Kulit dan Kelamin RSUP Prof. Dr. R. D. Kandou Manado selama periode tahun 2013-2015. Jenis penelitian ialah retrospektif menggunakan rekam medik pasien anak baru dengan infeksi kulit karena virus, berusia 0-14 tahun periode tahun 2013-2015. Hasil penelitian mendapatkan 113 pasien anak $(12,71 \%)$ dengan penyakit infeksi kulit karena virus, paling sering pada kelompok usia 5-14 tahun $(73,45 \%)$, diikuti dengan usia $1-4$ tahun $(25,66 \%)$ dan usia $0-1$ tahun $(0,88 \%)$; lebih banyak pada anak perempuan $(52,21 \%)$. Penyakit infeksi kulit karena virus terdiri dari moluskum kontagiosum $(47,79 \%)$, veruka vulgaris $(29,20 \%)$, varisela $(8,85 \%)$, herpes zoster $(7,97 \%)$, dan hand foot mouth disease $(6,19 \%)$. Simpulan: Penyakit infeksi kulit karena virus pada anak didapatkan sebanyak $12,71 \%$ dari pasien baru, terbanyak pada kelompok usia 5-14 tahun dan jenis kelamin perempuan. Moluskum kontagiosum ditemukan terbanyak pada semua kelompok usia.
\end{abstract}

Kata kunci: penyakit kulit, infeksi virus, anak 
Kulit merupakan organ tubuh yang berfungsi sebagai pertahanan yang terus menerus terpengaruh oleh lingkungan luar dan selalu beradaptasi dengan perubahan lingkungan. ${ }^{1}$ Struktur kulit dewasa dan anak sama, tetapi kulit anak lebih peka dan fungsinya belum berkembang dengan sempurna sehingga memudahkan terjadinya infeksi kulit baik oleh bakteri, jamur maupun virus. ${ }^{1,2}$ Infeksi tersebut sering memberikan gejala klinis yang berbeda dengan orang dewasa sehingga menyulitkan dalam menegakkan diagnosis. ${ }^{1}$

Hampir semua anak pasti pernah mengalami infeksi kulit. $^{3}$ Infeksi kulit dapat dicetuskan oleh beberapa hal, antara lain: kondisi imunologik, keutuhan kulit, status gizi, faktor lingkungan (panas dan kelembaban), dan kurangnya sanitasi dan higiene. $^{4}$

Virus adalah organisme ultramikroskopik yang berkembang dalam sel yang hidup. $^{2}$ Virus memiliki 3 jalan untuk menginfeksi kulit yaitu: autoinokulasi langsung, penyebaran lokal dari infeksi internal, dan lewat infeksi sistemik. ${ }^{5}$ Lesi kulit merupakan tanda khas dari beberapa penyakit akibat virus. ${ }^{6}$ Virus dapat menyebabkan manifestasi mukokutaneus sebagai hasil dari replikasi virus di epidermis atau pun sebagai efek sekunder dari replikasi virus di tempat lain pada tubuh. $^{5-6}$ Manifestasi lesi kulit dari infeksi virus dapat bervariasi mulai dari yang paling spesifik seperti vesikel dari herpes zoster sampai yang paling umum seperti urtikaria. $^{2,5-6}$

Penyakit infeksi kulit karena virus dapat terjadi pada segala usia, tetapi lebih banyak terjadi pada anak-anak, ${ }^{7}$ terutama pada usia sekolah. Hal ini dapat disebabkan aktivitas anak yang tinggi sehingga mempermudah untuk terkontak dengan agen penyebab infeksi. ${ }^{8}$

Profil penyakit infeksi kulit karena virus pada anak bervariasi di berbagai rumah sakit pendidikan di Indonesia. Pada Poliklinik Kulit dan Kelamin RSUP Dr. Mohammad Hoesin Palembang periode tahun 2005-2008, penyakit infeksi kulit karena virus pada anak ditemukan sebanyak $440(13,56 \%)$ pasien dari 3246 pasien anak dan merupakan penyakit ke-2 terbanyak dari penyakit kulit pada anak, ${ }^{9}$ sedangkan pada Poliklinik Kulit dan Kelamin RS Dr. M. Djamil Padang periode tahun 2003-2007, penyakit infeksi kulit karena virus pada anak merupakan penyakit ke-5 terbanyak dari penyakit kulit pada anak, yaitu sebanyak $187(9,28 \%)$ dari 2016 pasien anak.

Di Manado, data yang dilaporkan periode tahun 2008-2012 terdapat 213 $(14,88 \%)$ pasien anak dengan penyakit infeksi kulit karena virus dari total 1431 pasien anak dengan infeksi kulit di Divisi Dermatologi Anak Poliklinik Kesehatan Kulit dan Kelamin RSUP Prof. Dr. R.D. Kandou Manado. ${ }^{10}$

Penelitian ini bertujuan untuk mengetahui profil penyakit infeksi kulit karena virus pada anak di Divisi Dermatologi Anak Poliklinik Kesehatan Kulit dan Kelamin RSUP Prof. Dr. R.D. Kandou Manado selama kurun waktu 3 tahun sejak Januari 2013 sampai Desember 2015.

\section{METODE PENELITIAN}

Jenis penelitian ini ialah deskriptif retrospektif dengan mengumpulkan catatan rekam medik pasien anak baru dengan penyakit infeksi kulit karena virus di Divisi Dermatologi Anak Poliklinik Kesehatan Kulit dan Kelamin RSUP Prof. Dr. R.D. Kandou Manado selama kurun waktu 3 tahun sejak Januari 2013 sampai Desember 2015 yang merupakan subyek penelitian.

\section{HASIL PENELITIAN}

Pada hasil evaluasi retrospektif yang dilakukan di Divisi Dermatologi Anak Poliklinik Kesehatan Kulit dan Kelamin RSUP Prof. Dr. R. D. Kandou Manado selama kurun waktu 3 tahun sejak Januari 2013 sampai Desember 2015 terdapat 113 pasien $(12,71 \%)$ dengan infeksi kulit karena virus dari 889 kunjungan pasien anak secara keseluruhan (Tabel 1) dan penyakit infeksi kulit karena virus merupakan urutan ke-4 penyakit terbanyak (Tabel 2). 
Distribusi menurut usia terbanyak pada kelompok usia 5-14 tahun sebanyak 83 pasien $(73,45 \%)$, diikuti kelompok usia 1-4 tahun sebanyak 31 pasien $(25,66 \%)$, dan kelompok usia $0-<1$ tahun sebanyak 1 pasien $(0,88 \%)$ (Tabel 3).

Selama kurun waktu 3 tahun (2 Januari 2013 sampai Desember 2015) di Divisi Dermatologi Anak Poliklinik Kesehatan Kulit dan Kelamin RSUP Prof. Dr. R.D. Kandou Manado, ditemukan pasien lakilaki sebanyak 54 pasien $(47,79 \%)$ dan perempuan sebanyak 59 pasien $(52,21 \%)$ dengan ratio 1:1,09 (Tabel 4).

Data distribusi menurut jenis kelamin menunjukkan bahwa moluskum kontagiosum dan veruka vulgaris lebih banyak ditemukan pada pasien laki-laki, sedangkan varisela, herpes zoster, dan hand foot mouth disease lebih banyak ditemukan pada pasien perempuan (Tabel 5). Moluskum kontagiosum merupakan penyakit infeksi kulit karena virus terbanyak yang ditemukan selama kurun waktu penelitian dan juga terbanyak pada semua kelompok usia. Pada kelompok usia $0-<1$ tahun ditemukan $1(0,88 \%)$ pasien hand foot mouth disease. Pada kelompok usia 1-4 tahun ditemukan moluskum kontagiosum sebagai jenis penyakit terbanyak yaitu 17 pasien $(15,04 \%)$, diikuti hand foot mouth disease 5 pasien $(4,42 \%)$, veruka vulgaris 4 pasien $(3,54 \%)$, varisela 2 pasien $(1,77 \%)$, dan herpes zoster sebanyak 1 pasien $(0,88 \%)$. Pada kelompok usia 5-14 tahun ditemukan moluskum kontagiosum sebagai jenis penyakit kulit infeksi virus yang terbanyak yaitu 37 pasien $(32,74 \%)$, veruka vulgaris sebagai terbanyak ke-2 yaitu 29 pasien $(25,66 \%)$, urutan ke-3 ialah varisela dan herpes zoster masing-masing sebanyak 8 pasien $(7,08 \%)$ dan terakhir ialah hand foot mouth disease sebanyak 1 pasien $(0,88 \%)$ (Tabel 6).

Tabel 1. Distribusi penyakit infeksi kulit karena virus pada anak di Poliklinik Kulit dan Kelamin RSUP Prof. Dr. R.D. Kandou Manado Januari 2013 sampai Desember 2015

\begin{tabular}{lcccc}
\hline Pasien & \multicolumn{3}{c}{ Tahun } & Jumlah \\
\cline { 2 - 4 } & $2013(\%)$ & $2014(\%)$ & $2015(\%)$ & $(\%)$ \\
\hline $\begin{array}{l}\text { Penyakit infeksi } \\
\text { kulit karena virus }\end{array}$ & $24(2,70 \%)$ & $55(6,19 \%)$ & $34(3,82 \%)$ & $113(12,71 \%)$ \\
Penyakit lainnya & $327(36,11 \%)$ & $254(28,57 \%)$ & $201(22,61 \%)$ & $889(100 \%)$ \\
\hline
\end{tabular}

Tabel 2. Distribusi penyakit kulit pada anak di Poliklinik Kulit dan Kelamin RSUP Prof. Dr. R. D. Kandou Manado Januari 2013 sampai Desember 2015

\begin{tabular}{ccccc}
\hline Penyakit & \multicolumn{3}{c}{ Tahun } & Total (\%) \\
\cline { 2 - 4 } & $\mathbf{2 0 1 3}(\mathbf{\%})$ & $\mathbf{2 0 1 4}(\mathbf{\%})$ & $\mathbf{2 0 1 5}(\mathbf{\%})$ & \\
\hline Dermatitis & $116(13.05 \%)$ & $80(8,99 \%)$ & $37(6,52 \%)$ & $254(28,57 \%)$ \\
Penyakit infeksi karena & 66 & 53 & 41 & 160 \\
bakteri & $(7,42 \%)$ & $(5,96 \%)$ & $(4,61 \%)$ & $(17,99 \%)$ \\
Penyakit infeksi kulit & 24 & 55 & 34 & 113 \\
karena virus & $(2,7 \%)$ & $(6,19 \%)$ & $(3,82 \%)$ & $(12,71 \%)$ \\
Penyakit infeksi kulit & 51 & 27 & 13 & 91 \\
karena jamur & $(5,74 \%)$ & $(3,04 \%)$ & $(1,46 \%)$ & $(10,24 \%)$ \\
Alergi & $19(2,14 \%)$ & $29(3,26 \%)$ & $10(1,12 \%)$ & $58(6,52 \%)$ \\
Penyakit eritroskuamosa & $9(1,01 \%)$ & $4(0,45 \%)$ & $7(0,79 \%)$ & $20(2,25 \%)$ \\
Kelainan pigmen & $12(1,35 \%)$ & $11(1,24 \%)$ & $1(0,11 \%)$ & $24(2,7 \%)$ \\
Penyakit infeksi karena & $40(4.49 \%)$ & $40(4,49 \%)$ & $59(6,64 \%)$ & $139(15,63 \%)$ \\
parasit & & & & \\
Kelainan kelenjar sebasea & $5(0,56 \%)$ & $7(0,79 \%)$ & $5(0,56 \%)$ & $17(1,91 \%)$ \\
dan kelenjar keringat & & & & \\
Tumor kulit & $3(0,34 \%)$ & $3(0,34 \%)$ & $7(0,79 \%)$ & $13(1,50 \%)$ \\
Total & $345(38,81 \%)$ & $304(34,76 \%)$ & $235(26,43 \%)$ & $889(100 \%)$ \\
\hline
\end{tabular}


Tabel 3. Distribusi penyakit infeksi kulit karena virus pada anak setiap tahun menurut usia di Poliklinik Kulit dan Kelamin RSUP Prof. Dr. R.D. Kandou Manado Januari 2013 sampai Desember 2015

\begin{tabular}{|c|c|c|c|c|}
\hline \multirow[b]{2}{*}{ Pasien } & \multicolumn{3}{|c|}{ Tahun } & \multirow[b]{2}{*}{$\begin{array}{c}\text { Jumlah } \\
(\%)\end{array}$} \\
\hline & $\begin{array}{c}2013 \\
(\%)\end{array}$ & $\begin{array}{c}2014 \\
(\%)\end{array}$ & $\begin{array}{c}2015 \\
(\%)\end{array}$ & \\
\hline $0-<1$ tahun & $1(0,88 \%)$ & - & - & $1(0,88 \%)$ \\
\hline 1 - 4 tahun & $7(6,19 \%)$ & $13(11,50 \%)$ & $9(7,96 \%)$ & $29(25,66 \%)$ \\
\hline $5-14$ tahun & $16(14,16 \%)$ & $42(37,17 \%)$ & $25(22,12 \%)$ & $83(73,45 \%)$ \\
\hline Jumlah & $24(21,24 \%)$ & $55(48,67 \%)$ & $36(30,09 \%)$ & $113(100 \%)$ \\
\hline
\end{tabular}

Tabel 4. Distribusi penyakit infeksi kulit karena virus pada anak setiap tahun menurut jenis kelamin di Poliklinik Kulit dan Kelamin RSUD Prof. dr. R.D. Kandou Manado Januari 2013 sampai Desember 2015

\begin{tabular}{lcccc}
\hline \multirow{2}{*}{ Kelamin } & \multicolumn{3}{c}{ Tahun } & \multirow{2}{*}{ Jumlah (\%) } \\
\cline { 2 - 4 } & $2013(\%)$ & $2014(\%)$ & $2015(\%)$ & \\
\hline Laki-laki & $9(7,965 \%)$ & $30(26,549 \%)$ & $15(13,274 \%)$ & $54(47,788 \%)$ \\
Perempuan & $15(13,274 \%)$ & $25(22,124 \%)$ & $19(16,814 \%)$ & $59(52,212 \%)$ \\
Total & $24(21,239 \%)$ & $55(48,672 \%)$ & $34(30,088 \%)$ & $113(100 \%)$ \\
\hline
\end{tabular}

Tabel 5. Distribusi jenis penyakit infeksi kulit karena virus pada anak menurut jenis kelamin di Poliklinik Kulit dan Kelamin RSUP Prof. Dr. R. D. Kandou Manado Januari 2013 sampai Desember 2015

\begin{tabular}{cccc}
\hline Jenis penyakit & \multicolumn{2}{c}{ Jenis kelamin } & Jumlah \\
\cline { 2 - 3 } & Laki-laki & Perempuan & $(\%)$ \\
\hline Moluskum kontagiosum & $29(25,66 \%)$ & $25(22,12 \%)$ & $54(47,79 \%)$ \\
Veruka Vulgaris & $17(15,04 \%)$ & $16(14,16 \%)$ & $33(29,20 \%)$ \\
Varisela & $3(2,65 \%)$ & $7(6,19 \%)$ & $10(8,85 \%)$ \\
Herpes Zoster & $3(2,65 \%)$ & $6(5,31 \%)$ & $9(7,96 \%)$ \\
Hand foot mouth disease & $2(1,77 \%)$ & $5(4,42 \%)$ & $7(6,19 \%)$ \\
Jumlah & $54(47,79 \%)$ & $59(52,21 \%)$ & $113(100 \%)$ \\
\hline
\end{tabular}

Tabel 6. Distribusi Jenis penyakit infeksi kulit karena virus pada anak menurut usia di Poliklinik Kulit dan Kelamin RSUO Prof. Dr. R. D. Kandou Manado Manado Januari 2013 sampai Desember 2015

\begin{tabular}{lcccc}
\hline Jenis penyakit & \multicolumn{3}{c}{ Kelompok usia } & Jumlah (\%) \\
\cline { 2 - 4 } & $0-<1$ tahun (\%) & $1-4$ tahun $(\%)$ & $5-14$ tahun $(\%)$ & \\
\hline Moluskum & & $17(15,04 \%)$ & $37(32,74 \%)$ & $54(47,79 \%)$ \\
kontagiosum & - & $4(3,54 \%)$ & $29(25,66 \%)$ & $33(29,20 \%)$ \\
Veruka vulgaris & - & $2(1,77 \%)$ & $8(7,08 \%)$ & $10(8,85 \%)$ \\
Varisela & - & $1(0,88 \%)$ & $8(7,08 \%)$ & $9(7,96 \%)$ \\
Herpes Zoster & - & $5(4,42 \%)$ & $1(0,88 \%)$ & $7(6,19 \%)$ \\
$\begin{array}{l}\text { Hand foot mouth } \\
\text { disease }\end{array}$ & $1(0,88 \%)$ & $29(25,66 \%)$ & $83(73,45 \%)$ & $113(100 \%)$ \\
Jumlah & $1(0,88 \%)$ & &
\end{tabular}




\section{BAHASAN}

Di Indonesia, profil penyakit infeksi kulit karena virus pada anak bervariasi di berbagai rumah sakit pendidikan di Indonesia. Pada penelitian retrospektif ini, didapatkan penyakit infeksi kulit karena virus merupakan urutan ke-3 penyakit terbanyak pada Divisi Dermatologi Anak Poliklinik Kesehatan Kulit dan Kelamin RSUP Prof. Dr. R. D. Kandou Manado dari Periode tahun 2008-2013. Hal ini sesuai dengan penelitian sebelumnya yang dilakukan oleh Tanamal et al. ${ }^{9}$ di rumah sakit yang sama untuk periode tahun 20082013 yang juga menemukan bahwa penyakit infeksi kulit karena virus menempai urutan ke-4 penyakit terbanyak pada Divisi Dermatologi Anak. Urutan ini berbeda dengan penelitian Sylvia et al. ${ }^{8}$ di RS Dr. M. Djamil Padang yang melaporkan bahwa penyakit infeksi kulit karena virus merupakan penyakit ke-5 terbanyak dari penyakit kulit pada anak, serta penelitian Hutahean dan Soenarto ${ }^{10}$ di RSUP Dr. Mohammad Hosein Palembang yang mendapatkan penyakit infeksi kulit karena virus merupakan penyakit ke-2 terbanyak dari penyakit kulit pada anak.

Dari keseluruhan 889 kunjungan pasien anak di Divisi Dermatologi Anak Poliklinik Kesehatan Kulit dan Kelamin RSUP Prof. Dr. R. D. Kandou Manado Januari 2013 sampai Desember 2015 didapatkan $113(12,71 \%)$ pasien menderita penyakit infeksi kulit karena virus; paling banyak pada kelompok usia 5-14 tahun sebanyak 83 pasien $(73,45 \%)$, diikuti kelompok usia 1-4 tahun sebanyak 29 pasien $(25,66 \%)$ dan kelompok usia $0-<1$ tahun sebanyak 1 pasien $(0,88 \%)$. Hal ini sesuai dengan penelitian Waworuntu et al. $^{11}$ di RSUP Manado, Suhariyanto ${ }^{1}$ di RSUD Dr. Soebandi Jember, Sylvia et al. ${ }^{8}$ di RS Dr. M. Djamil Padang, Gaspersz et al. $^{12}$ di RSUP Prof. Dr. R. D. Kandou Manado, serta Hutahean dan Soenarto ${ }^{10}$ di RSUP Dr. Mohammad Hosein Palembang yang juga menemukan bahwa penyakit infeksi kulit karena virus pada anak paling banyak terjadi di kelompok usia 5-14 tahun. Tingginya insidens penyakit infeksi kulit karena virus pada kelompok usia tersebut dikarenakan pada usia ini anak sudah mulai bersekolah,,13-16 dengan aktivitas yang menjadi lebih banyak sehingga kemungkinan terjadinya kontak dengan lingkungan semakin tinggi yang mempermudah transmisi atau penularan. ${ }^{8}$

Selama kurun waktu 3 tahun (Januari 201-Desember 2015) di Divisi Dermatologi Anak Poliklinik Kesehatan Kulit dan Kelamin RSUP Prof. Dr. R. D. Kandou Manado ditemukan pasien laki-laki sebanyak 47,79\% dan perempuan sebanyak $52,21 \%$ dengan ratio $1: 1,09$. Hal ini berbeda dengan penelitian Waworuntu et al. $^{11}$ di RSUP Manado, Suhariyanto ${ }^{1}$ di RSUD Dr. Soebandi Jember, Gaspersz et al. ${ }^{13}$ di RSUP Prof. Dr. R. D. Kandou Manado, Ratnasari dan Zulkarnain ${ }^{17}$ di RSU Dr. Soetomo Surabaya, serta Tanamal et al. ${ }^{9}$ di RSUP Prof. Dr. R. D. Kandou Manado yang mendapatkan bahwa pasien laki-laki lebih banyak daripada pasien perempuan.

Data distribusi menurut jenis kelamin menunjukkan bahwa moluskum kontagiosum dan veruka vulgaris lebih banyak ditemukan pada pasien laki-laki dari pada pasien perempuan, sedangkan varisela, herpes zoster, dan hand foot mouth disease lebih banyak ditemukan pada pasien perempuan dari pada laki-laki. Kejadian herpes zoster yang lebih banyak pada pasien anak perempuan pada penelitian ini sesuai dengan acuan pustaka yang menyatakan bahwa herpes zoster lebih sering terjadi pada perempuan dibandingkan pada laki-laki, ${ }^{15}$ tetapi berbeda dengan hasil penelitian Gaspersz et al. ${ }^{12}$ dan Tanamal et al. ${ }^{9}$ keduanya di RSUP Prof. Dr. R. D. Kandou Manado, yang melaporkan bahwa herpes zoster lebih banyak ditemukan pada anak laki-laki daripada perempuan namun tidak berbeda mencolok. Dari distribusi data didapatkan juga bahwa hand foot mouth disease paling banyak ditemukan pada pasien anak perempuan; hal ini tidak sesuai dengan acuan pustaka yang menyebutkan bahwa kejadian hand foot mouth disease lebih tinggi pada anak laki-laki dibandingkan 
perempuan. $^{18}$

Pada penelitian ini moluskum kontagiosum ditemukan sebanyak 54 pasien $(47,79 \%)$ dan merupakan penyakit infeksi kulit karena virus terbanyak selama kurun waktu penelitian dan juga terbanyak pada semua kelompok usia. Hasil ini serupa dengan penelitian oleh Sylvia et al. ${ }^{8}$ di RS Dr. M. Djamil Padang, Ratnasari dan Zulkarnain $^{17}$ di RSU Dr. Soetomo Surabaya, dan Tanamal et al. ${ }^{9}$ di RSUP Prof. Dr. R. D. Kandou Manado yang juga mendapatkan bahwa moluskum kontagiosum merupakan jenis penyakit infeksi virus terbanyak pada anak. Urutan pertama ini agak berbeda dengan penelitan lainnya yang dilakukan oleh Waworuntu et al. ${ }^{11}$ dan Gaspersz et al. ${ }^{12}$ di RSUP Prof. Dr. R. D. Kandou Manado serta Suhariyanto ${ }^{1}$ di RSUD Dr. Soebandi Jember yang mendapatkan bahwa varisela ialah jenis penyakit infeksi virus terbanyak pada anak sedangkan Hutahean dan Soenarto ${ }^{10}$ di RSUP Dr. Mohammad Hosein Palembang mendapatkankan bahwa veruka vulgaris merupakan jenis penyakit infeksi virus terbanyak pada anak. Perbedaan urutan hasil penelitan ini mungkin disebabkan karena pola dan insidens penyakit kulit karena infeksi virus pada anak dipengaruhi oleh banyak hal, antara lain: keadaan kulit anak, higiene perorangan, gizi, dan aktivitas sehari-hari. ${ }^{6}$

\section{SIMPULAN}

Dari hasil penelitian terhadap pasien anak di Divisi Dermatologi Anak Poliklinik Kesehatan Kulit dan Kelamin RSUP Prof. Dr. R. D. Kandou Manado periode Januari 2012-Desember 2015 didapatkan 12,71\% pasien anak dengan penyakit infeksi kulit karena virus, terbanyak pada usia 5-14 tahun dan jenis kelamin perempuan. Moluskum kontagiosum ditemukan terbanyak pada semua kelompok usia.

\section{DAFTAR PUSTAKA}

1. Suhariyanto B. Pola penyakit anak kulit anak di RSUD Dr. Soebandi Jember. MDVI. 2006;33(4):157-61.

2. Paller AS, Mancini AJ. Hurwitz Clinical
Pediatric Dermatology (3rd ed). Philidelphia: Elsevier Saunders, 2006.

3. Sladen MJ, Johnston GA. Common skin infections in children. BMJ. 2004;329:95-99.

4. Boediardja SA. Epidemiologi penyakit infeksi serta peran sawar kulit pada infeksi mikroorganisme pada kulit bayi dan anak. In: Boediardja SA, Sugito TL, Kurniati DD, Elandari, editors. Infeksi Kulit pada Bayi dan Anak. Jakarta: Balai Penerbit FK UI, 2003; p. 3-5.

5. Tyring SK. Cutaneus virology. In: Tyring SK, editor. Mucocutaneus Manifestations of Viral Diseases. New York: Marcel Dekker Inc, 2002; p. 1-24.

6. Morrison KL, Ahmed A, Madkan V, Mendoza N, Tyring S. Viral disease: general considerations. In: Goldsmith LA, Katz SI, Gilchrest BA, Paller AS, Leffel DJ, Wolff K, editors. Fitzpatrick's Dermatology in General Medicine (8th ed). New Yok: McGraw Hill, 2012; p. 2329-36.

7. Caserta MT. Overview of viral infection in children. New Jersey: Merck \& Co Inc, 2007. [cited 2015 June 25]. Available from:

www.merckmanuals.com/home/childre ns_health_issues/viral_infections_in_in fants_and_children/overview_of_viral_ infections_in_children.html

8. Sylvia L, Gustia R, Hakim Z, Isramihati, Lestari S, Yenny SW, et al. Pola penyakit kulit anak di Poliklinik Ilmu Kesehatan Kulit dan Kelamin RS Dr. M. Djamil Padang Tahun 2003 -2007. Kumpulan naskah ilmiah Kongres Nasional ke-XII Perdoski. Palembang, 2-5 Juli 2008.

9. Tanamal RS, Lasut MV, Pandaleke HEJ.. Pola dan insiden penyakit infeksi kulit karena virus di Divisi Dermatologi Anak Poliklinik Kesehatan Kulit dan Kelamin RSUP Prof. Dr. R. D. Kandou Manado tahun 2008-2009. JBM. 2015;7(1): 54-61.

10. Hutahean NB, Soenarto K. Pola dan insidens penyakit kulit pada anak di RSUP Dr. Mohammad Hoesin Palembang. MDVI. 2010;37(4):154-8.

11. Waworuntu LV, Niode NJ, Pandaleke HEJ, Warouw WFT. Infeksi virus pada anak di Bagian Ilmu Penyakit Kulit dan Kelamin RSUP Manado 
Januari 1998-Desember 2002. Tidak dipulikasikan.

12. Gaspersz S, Jackqueline S, Pandaleke HEJ, Kartini A. Penyakit kulit infeksi di Divisi Dermatologi Anak Poliklinik Kesehatan Kulit dan Kelamin RSUP Prof. Dr. R. D. Kandou Manado. Kumpulan makalah lengkap Pekan Ilmiah Tahunan ke-X Perdoski. Jakarta, 20-31 Oktober 2009.

13. Wargon O. Human papilloma virus. In: Schchner LA, Hansen RC, editors. Pediatric Dermatology (4th ed) Philadelphia: Elsevier Mosby, 2011; p. 1460-9.

14. Sterling JC. Virus infections. In: Burns DA, Breathnach SM, Cox NH, Griffths CEM, editors. Rook's Textbook of Dermatology (8th ed). Massachussetts: Blackwell publishing Ltd, 2010; p. 33.1-78.

15. Wargon O. Varicella - zoster infections. In:
Schchner LA, Hansen RC, editors. Pediatric Dermatology (4th ed). Philadelphia: Elsevier Mosby, 2011; p. 1453-8.

16. Galen WK. Cutaneus manifestation of enterovirus infections. In: Tyring SK, editor. Mucocutaneus Manifestations of Viral Diseases. New York: Marcel Dekker Inc, 2002; p. 455-72.

17. Ratnasari DT, Zulkarnain I. Pola penyakit infeksi kulit pada bayi di Divisi Dermatologi Anak URJ Kesehatan Kulit dan Kelamin RSUD Dr. Soetomo Surabaya periode 2005-2007. Kumpulan makalah lengkap Pekan Ilmiah Tahunan ke-X Perdoski. Jakarta, 20-31 Oktober 2009.

18. James WD, Berger TG, Elston DM. Viral disease. Andrews Diseases of the Skin Clinical Dermatology (11th ed). Philadelphia: Elsevier Saunders, 2011; p. 367-420. 